\title{
Review of Georgian Leasing Market and Perspectives for Development
}

\author{
Nino Orjonikidze \\ Professor at Gori State Teaching University, Georgia \\ Nino Liparteliani \\ Professor at Gori State Teaching University, Georgia
}

\begin{abstract}
At contemporary stage leasing has formed as one of the dynamically growing trend that encourages investment progressions throughout the world business development. In the modern world, leasing acts as a multimillion industry. $80 \%$ of companies in developed countries use this financial instrument. 1/3 of investments in fixed assets are accomplished by means of leasing. Leasing companies have quite diverse business and operations. All these depend on lease term, type of relation, form of object, organizational structure of a company, etc. Leasing essentially is a whole complex of three simultaneously executed operations (lease, crediting and material support). At certain point, leasing is similar to credit, which is given to buy an object. Consequently, it may be called a property credit. Nowadays, in Georgia, banking credit is more well-known than leasing, in spite of the fact that for entrepreneurs leasing is more convenience than banking credit.
\end{abstract}

Keywords: Leasing, advantage, alternative, calculation, leasing market.

\section{Introduction}

The methodology of the study: During the research we used the following general-scientific methods: analysis by synthesis, observation, comparison, hypothesis and analogy.

\section{Review of Georgian Leasing Market and Perspectives for Development}

In the modern world, leasing acts as a multimillion industry. $80 \%$ of companies in developed countries use this financial instrument. $1 / 3$ of investments in fixed assets are accomplished by means of leasing. In Georgia, leasing relations started to develop in 1997. Certain leasing operations had taken place before legislative control was established for leasing relations. For example, in April 8, 1997, governments of Japan and Georgia entered into an agreement according to which Japan granted unremunerated assistance for Georgia. The grant included $\$ 4$ million. In the following years, China and Greece also made grant to Georgia for assisting the leasing business. In Georgia, leasing business is controlled by articles 576-580 of Georgian Code and Law of Georgia "Regarding Assistance for Leasing Business" which was adopted in 2002.

Leasing business is one of the types of entrepreneurial activity which accompanied the establishment of marketeconomic model in Georgia. In Georgia, leasing market is the only area where demand exaggerates supply, while there is high competition in other entrepreneurial activities. Despite Georgia has a law "Regarding Leasing Business" and credit resource, leasing alternative is quite expensive, as a result of which neither small and middle-scale companies, nor large companies very often do not have access to leasing. Leasing sector is basic factor for economic progress of a country, though it plays less important part in Georgian economics.[3] Development of leasing sector shall promote economic progress in the country and especially increase small and middle-scale business. In Georgia, there are 138 registered leasing companies while actually less than $10 \%$ of them work. Today, acting leasing companies in Georgia fund following fields: construction, health care, transportation and utilities, trade and manufacture industry, agriculture, printing trades and polygraphy. 
In Developing countries, 3-15\% of investments required for constant capital renovation are financed from leasing, while in developed countries this value reaches $30 \%$. In Georgia, as in a developing country, leasing finances approximately $2 \%$ of total assets, while the rest $98 \%$ appeal for banking, microfinance loans or their private resources to purchase primary means. Leasing in Georgia has not yet been developed properly, though, compared to common loan, it has lots of advantages. Security for mortgage is not required while taking a lease of property, as the subject of leasing is itself a guarantee. Return of lease property or terms of final purchase is agreed with lease recipient, finances are established in accordance with 100\% demand and lease payment is less than bank's beneficial interest. The founders of lease companies are mainly banks and financial institutions because a client prefers to receive credit not in the form of money, but receive the property which is the subject of purchase. Although, banks are not allowed to perform leasing operations directly. [1]

Setting up an agreement is simple and does not require financial expenses. In Georgia, lease companies offer clients a financial leasing and leaseback. Terms of financial leasing are from 5 to 15 years. The lease company purchases the equipment/machinery chosen by the client and leases it to the client for monthly lease payments in return. The lessee uses the asset for the business, makes payments every month and after covering the whole liability becomes the owner of the machinery. In case of leaseback, the lease company buys client's fixed assets and gives them with financial leasing. The lessee continues to use the assets and once the payment is fully covered the he/she gets back the ownership again.[4]

Today, financial leasing holds an important part of portfolios of lease companies. This type of leasing is popular especially in those countries where lease industry is on inceptive stage.

Non-existence of secondary machines is related to a high risk. In such countries, lease companies cannot offer customers a possibility to receive machines back because a second-hand sale of machines is a big problem. At present, lease companies in Georgia take risks that are related to crediting but not to lease item.

Work of lease companies in Georgia According to specialization

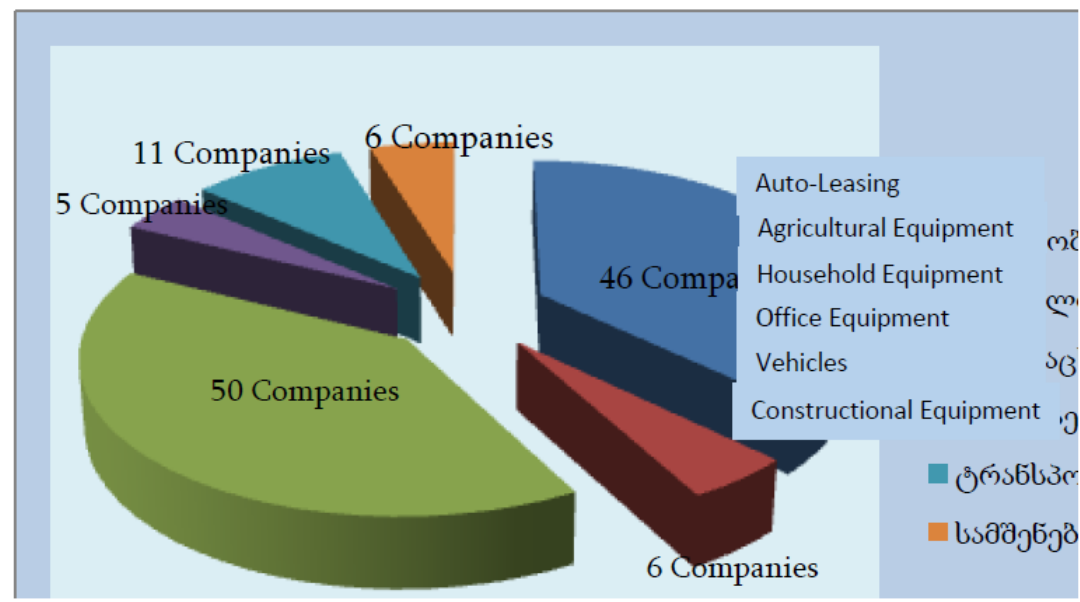

According to legal forms lease companies are divided in the following way: joint-stock company - $11 \%$, joint liability company - $23 \%$, individual company $-37 \%$, limited liability company $-27.6 \%$, mixed companies and cooperatives $-0.7 \%$ relatively.

Most part (almost 50\%) of lease companies existing in Georgia are registered in Tbilisi and their place of work is Tbilisi. The reason is that Tbilisi is more active in business than other cities of Georgia. $19 \%$ of companies (26 companies) are registered in Kakheti, $10 \%$ (14 companies) - in Imereti, 6.5\% (9 companies) - in Kvemo Kartli, 6\% (8 companies) - in Shida Kartli, 5\% (6 companies) in Samegrelo-Zemo Svaneti, etc. Such uniformity is caused as a result of irregular demand on leasing service in Georgian territory.[2] 
Georgia has a big potential for developing a lease market and it was encouraged by reforms made in civil and tax legislation in 2011. These reforms mitigated the leasing service and regulated the tax accounts for lessor and lessee. Preparation of draft law had been taking place for several months. The process involved appropriate governmental structures, as well as representatives from lease companies, business association and international experts. The law was approved by Parliament of Georgia in November 1, 2011. Following these reforms in Civil Code, leasing was registered as an independent agreement. Before that leasing was a type of rent.

According to the existing statistics, there are 3 leading lease companies in local market of Georgia:

"TBC Leasing" of TBC Bank;

"Georgian Leasing Company" of Bank of Georgia;

"Alliance Group Leasing" - an independent lease company.

JSC TBC Leasing was established in 2003. The company with up to 600 clients across Georgia and over 1500 valid leasing agreements, is currently the leader of the market with $69 \%$ share and manages GEL $102 \mathrm{~mm}$ portfolio. There are 53 employees in the company. The list of TBCL clients vary from medical, printing, transportation companies, food and processing industry, to service industry and trade, as well as some agricultural companies all across Georgia. The company participates in government programs ("Produce in Georgia", Georgian Rural Development Fund, Cheap Agro-Credit). The company has been offering the customers exclusive conditions on auto-leasing since 2015 - financing for new, second-hand, local or imported automobiles is available both for individuals and legal entities. For individuals this is the first product that was offered by the company. Prompt and flexible service makes TBCL products attractive for both newly established yet developing and accomplished large companies. The company constantly strives to develop partnership with local vendors and thus offer clients flexible new products. Being a leader on Georgian leasing market, TBC Leasing has a number of reliable partners both on local and international market: BSTDB, EBRD, RESPONSABILITY, SYMBIOTICS, MICROVEST, TRIPLE JUMP, etc.

The sectors that are financed by TBC Leasing are as follows: medicine, service, development, construction, Road construction, industrial (agro, producing, trading), natural recourses, renewable energy, technologies, media and telecommunications. Terms of Financial leasing: average price of asset $-\$ 25,000-\$ 1,000,000$; term $-12-84$ months; standard implicit rate - 15-35\%; guarantee: the purchased machinery.

TBC Leasing is applied by many companies. By 2016, TBC Leasing whole leasing portfolio was more than 8 million dollars with over 90 financed projects. TBC Leasing has active relations with international organizations and with their direct support holds a dominant position in Georgia.

EBRD made decision to purchase $10 \%$ of stocks of TBC Leasing Company. This was the first investment that was made in Georgian leasing market. EBRD issued a credit for TBC Leasing with the amount of 3 million dollars. Such investment encourages both successful business of TBC Leasing and also development of newly created leasing market of Georgia. The credit of EBRD is for 5 years that enables TBC Leasing to perform lease projects with private, small and middle-scale Georgian companies.

Demand on leasing between enterprises in TBC Leasing portfolio are divided in the following way $15 \%$ of customers - small productions; $55 \%$ - medium-sized; $30 \%$ - large companies.

In 2014, TBC Leasing was financed with USD 4 million loan. The facility was issued by the Black Sea Trade and Development Bank (BSTDB). The facility will be used to finance small- and medium-sized local companies. The new loan extended by BSTDB to TBC Leasing serves increasing access to the finances for Georgian small- and medium-sized companies through development of nonbanking finance sector in Georgia. Leasing as a tool for investment in equipment promotes economic growth and consequently, creation of employment. 


\begin{tabular}{|c|c|}
\hline Best Equity Fund (LHV Persian Gulf Fund) GCC 2015 & LHV Asset Management \\
\hline Best Asset Manager GCC 2015 & United Securities LLC \\
\hline $\begin{array}{l}\text { Best New GCC Fund } 2015 \text { - SEDCO Capital GCC Equities } \\
\text { Fund }\end{array}$ & Sedco Capital \\
\hline Fastest Growing Retail Bank Gambia 2015 & FBNBank (The Gambia) Limited \\
\hline Best Retail Bank Gambia 2015 & Trust Bank Ltd \\
\hline Best Regional Trade Finance Bank Gambia 2015 & Ecobank Gambia ltd \\
\hline Best Banking Cards (Regional and Visa Card) Gambia 2015 & Ecobank Gambia ltd \\
\hline Best Commercial Bank Gambia 2015 & Guaranty Trust Bank (Gambia) Ltd \\
\hline Best Internet Bank Gambia 2015 & Guaranty Trust Bank (Gambia) Ltd \\
\hline Best Leasing Company Georgia 2015 & TBC Leasing \\
\hline Fastest Growing Corporate Bank Georgia 2015 & PASHA Bank \\
\hline Best Retail Bank Georgia 2015 & Liberty Bank \\
\hline Best E-commerce Bank Georgia 2015 & Capital Bank \\
\hline Best Investment Brokerage Company Georgia 2015 & Galt \& Taggart \\
\hline Best Corporate Finance Advisory Georgia 2015 & Galt \& Taggart \\
\hline
\end{tabular}

According to Global Banking \& Finance Review Awards-2015, TBC Leasing is the best leasing company of the year

\section{of 2015 in Georgia}

"Luca Polare", a popular ice-cream shop in Tbilisi, collaborates with TBC Leasing. In the begining of the business, purchase of technic equipment was funded by their partner. After that, the ice-cream cafe and production was expanded by the support from TBC Leasing. Today, they still collaborate with TBC Leasing and have many plans for the future. "Luca Polare" started its business with one ice-cream shop in Tbilisi, Leselidze street. Soon, they opened another cafe. At present time, they have five locations in Tbilisi. Support from partner is most important in competitive market.

The company works for establishment of new leasing projects that will give an opportunity of the customers to reduce monthly taxes: during the lease term the client will pay only part of the value of item and after the end of the period he/she will have an opportunity to return the old item back and take new. In September 2004, "TBC Leasing set up an agreement with "ADVANTAGE". "ADVANTAGE" is USAID financed project, which aims to help the export of Georgian agricultural products to increase.[10]

"Georgian Leasing Company", sub-company of Bank of Georgia, offers funding for purchasing the basic facilities. "Georgian Leasing Company" Ltd. (GLC) is a member of the JSC Bank of Georgia Group, with 15 years of experience in leasing services. GLC was the first company to offer customers leasing services as an alternative way of financing and continues successful implementation of this mission today. GLC provides an opportunity to start up business, SME's and large companies to acquire wide range of leasing services such as finance lease, Sales \& Leaseback and operating lease. GLC offers its leasing services to individuals as well. GLCs business relations with the clients is based on partnership and mutual understanding. GLC considers success of its clients as its own and offers services of highest quality tailored to the needs of clients. Bu use of leasing, you have a chance to purchase assets without capital outlays. As a result, you have an opportunity to save credit lines for business development. Leasing products are: financial leasing, auto-leasing, auto-leasing without financial records, auto-leasing with remainder cost, leasing of restaurant equipment, leaseback, operational leasing.

GLC and "Mercedes-Benz" official representatives in Georgia offer customers (individuals/legal entities) completely new product - "Auto-leasing _ Your New Mercedes". From today on, one of the most prestige and marketable brand "Mercedes-Benz" will become available for customer by means of auto- leasing. "Auto-leasing _ Your New Mercedes" allows customers to take advantage of so-called 'trade-in' which means that: an individual/legal person purchases a new car at "Mercedes-Benz" center and after some time if he/she wants to return the purchased model back and replace it with a new one, GLC and "Mercedes-Benz" official representatives give the possibility for that. Customers 
will also be able to redeem leased car and keep it in permanent use. First time in Georgia it is possible to purchase new "Mercedes" car by leasing based on minimal monthly lease cost and payment only $10 \%$ of car's price (implication). It should be noted that monthly lease cost does not cover set up, legal, purchase-related, insurance or other costs. It is important to mention that during car using the customers can have their cars checked at "Mercedes Benz" service center for free once in 6 months. Term of "Auto-Leasing - Your New Mercedes" is maximum 72 months. During auto-leasing customers can reduce their monthly lease cost by increasing implication (first payment). For example, if a customer prefers $30 \%$ implication, monthly lease cost for 72 months' period will be only $287 €$.

Alliance Group Leasing (AGL) is the first independent, non-banking leasing company in Georgia, which offer customers financial, operational leasing and leaseback services. Since it was established in 2006, the company has served over 4,000 customers and funded 40 million USD transactions. Except Tbilisi, the company's leasing service is available in Zugdidi Region. Alliance Group Leasing is the first leasing company in Georgia which was awarded with quality control international certificate ISO 9001 in 2011. Besides, Alliance Group Leasing is the first which was awarded with "portable guarantee" by US government in 2011. Alliance Group Leasing has special offer for wine producers, small and family wineries and touristic sites. In May 26, 2015, with regard to Independence Day of Georgia, Ministry of Environmental Protection hosted visitors at "Green City" on Rustaveli Avenue. Alliance Group Leasing represented electric bicycles at the corner of the city where visitors were able to be informed about technical specifications of the bicycles. The bicycles deserved great interest from the visitors. First time in Georgia, Alliance Group Leasing offers a unique, modern and easy way of transportation - electric bicycle. There are three types of Bicycles in sale: tourist i.e. mountain bicycle, city and cargo tricycles. Biking and maintenance of electric bicycles are very simple. It can be charged from houshold power supply. Electric bicycles can be used both in high mountain regions and also in lowlands and city. Electric bicycle is perfect for those People who follow a healthy lifestyle. Holidaymakers who want to take a ride in the city or in the mountains; Small and medium business and hotel employees in the regions who have to travel from village to the city and vice versa and need to carry some goods. For interested people it is possible to purchase the bicycles by easy, leasing service.[12]

In Georgia government project "Produce in Georgia" started in June 1, 2014. The program budget is 46 million Lari. It aims to support small and medium-sized businesses and start-up companies. In October 2016, Georgian government added to program a new component - leasing. "Leasing Course" is a new direction of the program. Industrial machinery technologies are very old in Georgia and that's why the government will subsidize and provide far more cheap services for the program involved companies through existing leasing companies. This is a good opportunity to import technologies and new machineries in Georgia.

\section{Recommendations}

For development of leasing sector, it is required to work on new concept, according to which, new legislative ground will be established that will encourage to appear new sources of finances for assets, develop products and bring new investments in this field. According to the representatives of leasing market, leasing service prices will become cheap and more producers will come in the market as soon as leasing law is improved. It will increase the turnover of companies that consequently will cause set-back of prices on the assets. Finally, it will stimulate the companies to invest in fixed assets;

Development of leasing sector has direct relation to economic progress. Level of unemployment is lower in the countries where leasing operates properly compared with the countries where leasing is still in developing stage;

Proper leasing system provides successful business for small and medium-sized companies;

Profit of leasing companies was reduced by high taxation regime that is active in Georgia. Low profit margin is one of the main reasons that hindered the development of this market.

In Georgia, leasing business is taxed with VAT and this regulation still remains in legislation. Leasing is the best facility for developing small and medium-sized businesses. In foreign countries, Leasing is free from VAT and legislation regulated many other issues. In our country, leasing business is not free from VAT and consequently, using credit is cheaper than leasing. The owner of business prefers to take credit from bank rather than take leasing because VAT rate is added to monthly lease cost and in fact, the last one is more expensive. 
In Georgia, there are two types of leasing companies - existing at bank and independent leasing companies. Georgian legislation allows being of leasing companies existing at bank by consent from National Bank. The lack of finances is more a problem. At this stage, banks have less opportunity to expand and establish leasing companies. On the other hand, banks look at leasing companies as their competitors. Though, word experience shows that banks and leasing companies are in different segment and are not competitors for each other.

In Georgia, interest rate on loans of leasing companies is between $16 \%-20 \%$, which is too high and requires work to be reduced.

More work is required with local businessmen to make them aware of advantages of leasing and its economic benefit.

None of the leasing companies work in quite large regions of Georgia, such as Racha-Lechkhumi and Kvemo Svaneti. This region is less developed and its part in Georgian industrial production is only $0,3 \%$, still the recourse potential of this region makes it possible to develop.

Level of implication of customers in leasing should be cancelled by considering living conditions of our population.

We consider that market requires support and interfere from government on the beginning stage of leasing market formation where Georgia is now residing. Otherwise, it will not improve.

\section{Literature review}

The following materials from Georgian magazines were discussed during the work on the issue:

Practical-scientific journal "Accounting Records";

Informational-scientific journal "New Agricultural Georgia";

Methodic-practical journal "Taxations and Calculation";

Juridical journal by Association of Judges of Georgia "Justice and Law";

Materials for international scientific conference organized by Tbilisi Teaching University;

Collected works of Batumi Shota Rustaveli State University;

International practical-scientific journal by Guram Tavartqiladze University;

Addition of journal "Moambe" by Georgian National Academy of Sciences;

Scientific, practical-analytical journal "Business and Legislation";

Collected Scientific works of Paata Gugushvili Institute of Economics of Tbilisi State University.

\section{References}

[1] Alexandre Turmanidze. Types of Leasing and forms of their realization. Shota Rustaveli State University: works Ministry of Education and Science of Georgia; Batumi Shota Rustaveli State University. [V] III. Tbilisi; Batumi, 2011. p.157-168.

[2] Alexandre Zhgenti. Leasing: Financial Leasing. Business and Legislation: scientifis, practical- analytical journal. October. Tbilisi 2010. p.10-12.

[3] Elguja Chanturia. Leasing Agreement in English-Americal Law. Life and Law: International practical-scientific journal. N4(16), The issue was dedicated $65^{\text {th }}$ anniversary of Guram Tavartkiladze. Civil Law and Process. - reference- Tbilisi, 2011. p.83-84.

[4] Gvantsa Gvichia. Shota Macharashvili. Leasing is quite useful service for buying agricultural equipment and technologies. New Agricultural Georgia: research-scientific journal. March. N3(35). Tbilisi 2014. p.15-17.

[5] http://leasing.ge/ge/

[6] http://www.agl.ge/

[7] http://www.tbcleasing.ge/ 
[8] Internet Recourses:

[9] Karlo Bzishvili. Legal Nature of Leasing. Science and life. International, reviewed and abstracted scientific journal. Tbilisi Teaching University. N1(7), Globalization and Actual problems in $21^{\text {st }}$ century (Materials of international scientific conference). Tbilisi 2013. p.352-357.

[10] Ketevan Ormotsadze. Financial Leasing. Accounting Records practical-scientific journal. March. N3. Tbilisi, 2014. p.37-42.

[11] Khatuna Berishvili. Conditions of International Leasing and Perspectives for development in Georgia. Tbilisi 2012. p.131.

[12] Manana Kharkheli. Development of Leasing in Georgia and its economical-legal problems. Paata Gugushvili Institute of Economics: collected scientific works. University of Economics and Law of Georgia. V - I. Tendencies of Economics and Business Development in Georgia. Tbilisi, 2010. p.217-220.

[13] Manana Magradze, Nana Kopaliani, Elene Muchiauri, Investment Business of Enterprise - Leasing. Works: Addition of journal "Moambe" by Georgian National Academy of Sciences / Georgian National Academy of Sciences. N2(17). Tbilisi. p. 129-133.

[14] Nariman Terashvili. Classification and Registration of Leasing. Taxations and Calculation: Practical-methodic journal. February. N4. Tbilisi, 2014. p.9-11.

[15] Sophiko Meshvelishvili. Essence of Leasing Relations, Historical Review of its development, Specifications and Contemporary Definition. Justice and Law- Juridical journal. Association of Judges of Georgia. Supreme Court of Georgia. N4(39). Tbilisi 2013. p.81-93.

[16] Tatia Khaliani. Why is not Leasing Developing in Georgia? Liberal. 17-23 September. N107. Tbilisi 2012. p.34-36. 